\title{
A Brazil-Quebec joint venture on universities and participatory development
}

\author{
Gaëtan Tremblay* \\ Marcelo Marinho**
}

Recebido em 25/10/2009; revisado e aprovado em 25/1/2010; aceito em 26/2/2010

Following OECD's experts, whose theory has been adopted by most of Western governments, ongoing economic systems and contemporary societies rely more and more on the production and the control of knowledge. In modern societies, universities have been for a long time linked to economic, cultural and social development. Nowadays, their role as training and research centers is reinforced by the needs of the so called information and knowledge society, regarded as the closest future paradigm of both social development and wealth production (PETRELLA, 2000). The access to higher education and the creation of suitable conditions for the production and circulation of significant knowledge have become centre pieces of responsible development, in the rich countries as well as in the poor ones.

On another side, universities are in crisis almost everywhere in the world. They face serious financial difficulties, particularly in the public sector. Voices from different social groups invite them to reconsider their role in the new knowledge society, forecasted and legitimated by the World Summit on the Information Society, held in Geneva (2003) and Tunis (2005).

Although it is well known that the improvement of accessibility necessarily implies an increase in financial resources and a policy facilitating the participation of the marginalized people, the concrete mechanisms which support the transfer and the diffusion of knowledge are much less documented. They are however the object of constant concerns, in particular in certain innovative programs (for example: in local development, in environmental sciences, in tourist studies), and give rise to new researches and exploratory experiments aiming at promoting exchanges between the universities and the communities they serve.

Brazil and Quebec have been particularly fertile composts in this respect. On the one hand, the "Universite du Québec » network has been, since its inception at the end of the Sixties, a rich ground in experimenting new relations between the universities and the communities where they evolve, in terms of training as well as research. In addition, for a few years, the federal and provincial research-funding councils have adopted specific programs to encourage such initiatives. On the other hand, Brazil is home country to Paulo Freire, one of the most important thinkers on education in the twentieth century, originator and promoter of the pedagogy of autonomy and anchoring in the socio-economic reality of learning his theories have won large international recognition and inspired various Brazilian experiments.

Canadian professor Harold A. Innis accomplished pioneering work when he published his reflexions on universities' social responsabilities in the years 1940-1950. «The universities must concern themselves with the living rather that with the dead $\gg{ }^{1}$, he professed. But he believed these academic institutions should keep at arm's length the social, political and economic spheres to remain «objective», «unbiased». As wrote William Westfall, "he invested in the university the same sacred character that his Victorian ancestors had placed in the institutions of Ontario Protestantism. The graduate school, like the church, might be in the world, but it was not of it. It drew its essence from a source of knowledge that was

\footnotetext{
* Université du Québec à Montréal.

** Universidade Católica Dom Bosco, Campo Grande.
} 
above time and place» ${ }^{2}$. Other academics from various disciplines, extending the evolutionist theory to societies, applyed a diffusionist approach to development, trying to export the knowledge and the solutions adopted by Western Europe and North America. Since the seventies, these modernist, paternalist and neocoloniaslist models of the Post-war period have been severely criticized and disputed. They gave way to more participative, more respectful approaches to sociocultural diversity, autonomy and responsibility of the local communities.

The educational institutions, at which forefront the universities stand, are directly challenged and invited to yield their share in order to improve the population wellbeing. New functions, named services to the community, emerge progressively and the academics are often solicited to take part in projects and programs of local development. How to meet these new needs in full respect for the fundamental characteristics of universities' mission, that is to say the production and the transmission of the knowledge? How to do it equally in full respect for the communities' know how? These are central questions to people working in these new perspectives.

Our paper addresses these questions in three steps. The first one presents the Université du Québec à Montréal (UQAM) expertise and contribution to community services. The second one is dedicated to the Dom Bosco Catholic University involvement in participatory development. The third one explains the joint project initiated by the Center for Enquiries and Researches on Brazil (CERB), and supported by SSHRC ${ }^{3}$, involving four Quebec universities ${ }^{4}$ and five Brazilian ones ${ }^{5}$ in sharing their knowledge regarding the role of universities in local and regional development.

\section{UQAM's know-how regarding " services aux collectivités "}

The University of Quebec in Montreal (UQAM) has been created in 1969, in the mood of an historical period characterized by intensive aggiormamento on the campuses of Western Europe and North America aiming at redefining the society in general, and the universities in particular. Right at the beginning, "participation" has been identified as a core value of its structure and functionning. The students have been invited to participate to the curriculums' management on an equal basis with the academics. The professors have been involved at every level of the organization, representing a heavy weight in the decision process regarding all academic matters. And their working load has been defined as including not only teaching and research but also services to the community. Their commitment to participation is so strong that they went on strike for four months in 1976 to resist an attempt by the administration to reduce the power of the "Commission des études ", the central committee ruling teaching and research activities on which all groups in the university have a voting representation (students, academics, administrators, clerks).

The UQAM has played a pioneering role in the promotion of community services, involving academics who develop and manage training and research projects in partnership with community and popular groups, voluntary and autonomous associations, groups of women, workers' unions and other NGOs. The UQAM considers that providing services to the community is an essential part of its mission as a public service. The university adopted an official policy organizing and facilitating services to the local community as early as 1979. This policy leaded to the creation of a specific office, called "le service aux collectivités » (SAC), whose mission is to promote and coordinate professors' and students' collaborative initiatives with different social groups. The SAC's team includes, in 2007, a full time chairperson, four full time professionals (development agents) and one administrative officer. The SAC's activity is oriented and supervised by an institutional committee (CSAC) of eight academics representing the eight UQAM's faculties and an equal number of outside representatives from different social groups.

The SAC is structured in three "divisions » corresponding to the three categories of partners whom the UQAM's 
academics are mainly working with: the workers' unions, the women's associations and the communitary groups. The projects, always defined jointly by professors and social actors, include either training, research or diffusion activities responding to local needs. The SAC is typically an agency devoted to participatory development. Every activity supported by its members finds its origin in a social group request, be it a union, an association or a community. The teaching contents and methods are designed to meet expressed needs (for example: how to deal with the medias? how to organize meetings? how to facilitate collective work?), the research usually follows action research models (the group participates to the definition of the objectives and, according to every particular case, is more or less involved in the research process) and the diffusion activities are organized in partnership.

The expression of the social needs usually follows one of two paths, either through an academic already in touch with the requesting social group or through one of the four full time development agents working on a regular basis with the unions, the women movements or the communitary groups. In the first case, the researcher asks the SAC for institutional support, in the second one, the SAC's development agent tries to find a teacher or a researcher that would accept to meet the social request. Of course, the expression of needs is not always clear and precise. It usually gives rise to a discussion between the social group, the academics and the SAC's professionnals leading to an elaborated and structured proposal. It even occurs that ideas are suggested to the social group by the researcher when both have developped a stable relationship. These interactions are essential to the participatory development process. The social group is given the opportunity to explain its needs and priorities and the academics can contribute their say, avoiding to fall into a mere market relation between a client and a provider.

One can get detailed information regarding these activities consulting the SAC's annual reports ${ }^{6}$. To give an idea, here are some typical training activities organized over the 2002-2005 period with the financial support of the Quebec Ministry of Education :

- Feminism, citizen participation and the reform of democratic institutions, led by Professor Jocelyne Lamoureux, Department of Sociology. Done in cooperation with a group called Collectif Féminisme et démocratie, this project has led to the creation of a website ${ }^{7}$ on Women and Democracy, still running in 2007, providing useful information and documentation relevant to democratic participation. It pays particular attention to the debate regarding electoral reform.

- Citizen appropriation process of economic and social human rights in Quebec: understanding and giving reality to human rights, led by Professors Lucie Lamarche and Georges Lebel, Department of Law Sciences. This project has been conducted on request of La ligue des droits et libertés du Québec to help various community group to dialogue with experts on the International Covenant on Economic, Social and Cultural Rights, and further to identify violations of social and economic rights.

- Women, learning technologies and distance training, led by Professor Nicole Lebrun, Department of Education and Pedagogy. A partnership between the university and five feminist groups ${ }^{8}$ which aims to empower, through online training, women in the process of eliminating illitaracy in their search for a job and adult women in the process of professional reorientation. Their website ${ }^{9}$ is still running in 2007. This project is grounded in a related theoretical research undergone by the same team.

- Technologies of human reproduction: genesis, issues, risks and altenatives, led by Professor Louise Vandelac, Department of Sociology. This training project, answering a request from La Fédération québécoise pour le planning des naissances, is designed to inform people from vairous social groups about the risks of new human reproduction technologies.

- Sex workers, beyond prejudices : live and work in good health, security and dignity, led by Professor Mensah Maria Nengeh, 
School of Social Work. In cooperation with the Stella group ${ }^{10}$, this project is aiming to increase knowledge and circulate information on the sex workers' health and operating conditions. It also helps concerned people to intervene in public debate and on policy issues.

The university financial contribution to training activities takes the form of lightening some faculty members' teaching load. During the 2002-2005 period, the UQAM invested the equivalent of 32 regular classes, i.e. 1440 teaching hours, in training activities to the community.

Among the various research activities, let's quote:

- The modernization of Notre-Dame Street,led by Professors Donna Mergler, Department of Biological Sciences, and Laurent Lepage, Environmental Sciences Institute. Following the request of a Montreal neighbourhood citizen committee ${ }^{11}$, a comparative research has been conducted from 2001 to 2005 on the impact of urban transport infrastructure constructions on human health. A report has been produced and circulated.

- Public action and issues regarding wastes ecological management, led by Professor Laurent Lepage, Environmental Sciences Institute. Initiated by the Front commun québécois pour une gestion des déchets, the research assessed the efficiency of public mecanisms designed to raise citizen consciousness regarding recycling.

- Support networks in workers' unions, led by Professor Denis Harrisson, Department of Organization and Human Resource. An action research, initiated on request by the Confédération des Syndicats Nationaux (CSN), to evaluate the operation and users' satisfaction of the support networks created by the CSN in the Montreal area to help workers facing important changes in their working conditions and to suggest ways of consolidating and improving these support networks..

- Information practices in women's groups, led by Professor Sylvie Jochems, School of Social Work. On request of the Centre d'éducation des adultes et de la condition féminine, this action research intended to identify the information activities in women's groups, to assess their coherence and to suggest ways of fomenting the democratization access to knowledge in the feminist movement in the context of the information society.

- The invisible which hurts: Globalization and working women's health, led by Professors Karen Messing and Katherine Lippel, CINBIOSE. An important research program integrating many different projects (26 were ongoing in october 2007) on various aspects of working women's physical and mental health, focusing on the impact of globalization, conducted by the Centre d'étude des interactions biologiques entre la santé et l'environnement de l'UQAM in partnership with the three large Quebec Unions' federations (CSN, CSQ,FTQ) ${ }^{12}$, which has produced many significant reports. Over the years, the CINBIOSE, whose most prominent members have also developped projects in Brazil, has become a key player in developing fruitful partnership between Quebec's unions and the academics on workers' health.

The university involvement is also financial. As shown in table 1, the UQAM's contribution to subsidizing the activities reached $12 \%$ in the year 2004-2005. However, the major part of the funding comes from research granting agencies like the Social Sciences and Humanities Research Council of Canada (SSHRC), the Conseil Québécois de la Recherche Sociale (CQRS) and different provincial or federal governmental departments. The total budget reached more than a million dollars in 20042005 (Table 1). 
Table 1 - UQAM's share (internal funding) in the global financing of research projects, Service aux collectivités 2002-2005 ${ }^{13}$.

\begin{tabular}{|c|c|c|c|}
\hline & 2002-2003 & 2003-2004 & 2004-2005 \\
\hline Financement interne:Volet 2 du PAFARC & $40926 \$$ & $45000 \$$ & $47877 \$$ \\
\hline Financement total de la recherche & $446002 \$$ & $495903 \$$ & $389616 \$$ \\
\hline \% venant du financement interne à l'UQAM & $9 \%$ & $9 \%$ & $12 \%$ \\
\hline
\end{tabular}

Source: Le Service aux collectivités de l'UQAM, Rapport d'activités 2002-2005, p. 21

PAFARC: Programme d'aide financière à la recherche et à la création

Table 2 - Global Financing of activities, Service aux collectivités de l'UQAM 2002-2005

\begin{tabular}{|c|c|c|c|}
\hline Activités & $2002-2003$ & 2003-2004 & 2004-2005 \\
\hline Formation & $200559 \$$ & $324022 \$$ & $391135 \$$ \\
\hline Recherche & $446002 \$$ & $495903 \$$ & $389616 \$$ \\
\hline Diffusion/Expertise & $33700 \$$ & $10650 \$$ & $309800 \$$ \\
\hline Total & $680261 \$$ & $830575 \$$ & $1090551 \$$ \\
\hline
\end{tabular}

Source : Le service aux collectivités de l'uqam, rapport d'activités 2002-2005, p. 21

PAFARC : Programme d'aide financière à la recherche et à la création

The SAC has achieved remarkable results over more than a quarter of century. It has developped and applied successfully formal protocols to facilitate and regulate partnerships with workers' unions, community groups and women's associations. Of course, its activites have raised questions and met difficulties. Even in a university dedicated to increasing accessibility and open to social innovation, the old opposition between scientific quality and social relevance has feeded many debates. Action research as a trustable scientific methodology still raises doubts among colleagues. An important step forward has been made when SSHRC adopted his policy to favor community university research alliances (CURA), providing significant financial support and giving official acknowledment to the efforts undertaken by agencies like the SAC. But research teams like the CINBIOSE are still confronted to the funding agencies structures and policies that usually allow little room to multidisciplinary work. It is quite impossible for them, at the moment, to be recognized as offcial research centers and to get access to the related grants.

SAC's members are often perceived as isolationist by the rest of the UQAM's community, to such a degree that the improvement of relations with other academic units has been identified as a priority in the two last SAC's Activities Reports 2000-2002 and 2002-2005. The efforts undertaken in direction of the faculties and other administrative levels have produced positive results. But the danger remains that the SAC's activities be looked like « special », « different », « secondary », in comparison to traditional teaching and research so that the explaining and convincing work is not over.

Recruiting reseachers, especially young ones, to fulfill services to the community is a difficult task at the moment. The pressure for academic achievement in a context of acute competition pushes most colleagues towards activities more rewarding for their 
career progression: research grants applications and publishing in well known journals. It leaves little time even to the most motivated ones. To favour this mission of public service, it is absolutely necessary to adopt a promotion policy that gives equal load to services to the community and traditional research and teaching in the assessment of academic performance.

The SAC suffered huge budget cuts in 2002, having in particular to reduce the number of professionals working full time to search money for and to coordinate the many ongoing training and research projects. Giving the new financial problems facing UQAM in 2007, one fears further cuts in the allocation of resources to this service in the coming years. If the Quebec government does not quickly increase public subsidies to the universities, activities serving marginalized groups will be more damaged than the traditional ones. It would be quite depressive to return a quarter century backward.

\section{Communitarian universities,} participatory development and researchaction within the Pantanal and Cerrado region (Brazil)

In Brazil, a huge number of participatory development projects are led by communitarian universities, an innovative form of institution born some decades ago in the vacuum left between state-funded universities and private education enterprises. Whether they are secular or confessional, those universities are managed under the responsibility of nonprofit associations or foundations, under some conditions that reassert their belongness to the Third Sector, i.e. to the social sector set between private and public institutions, between profit-driven businesses and government services. The Third Sector includes organisations such as cooperatives, non-profit associations or nongovernmental organisations, with strong social commitments that lead them to reinvest their surpluses into their own organisation or into the surrounding community, rather than distributing profit to owners or shareholders.

The Brazilian National Congress describes the communitarian universities as praiseworthy with regard to public interest educational services, since they devote their surpluses to academic purposes and social projects (ASSEMBLÉIA NACIONAL CONSTITUINTE, 1987, p. 300). The 54 Brazilian communitarian universitites are organized under a national wide association (see www.abruc.org.br), that includes secular and confessional institutions, professional cooperatives or community lead educational initiatives.

Furthermore, Moacir Gadotti (1995, p. 5) sustains the idea that both state-funded and communitarian universities set their core difference on the financial funding structure rather than on pedagogical, social and political projects : the communitarian's action profile reflects widely its «character commited to public, social and communities matters». It's important to stress their contribution to the democratization of higher education access, thus to the very Human Development Index improvement in that South-American country, by means of multiplicating available university seats and innovative courses. In Brazil, the catholic institutions are commited to those goals, as well as to research on social matters. By the way, in the last five years national polls based on scientific research indicators rank catholic universities amongst the most productive institutions everywhere in Brazil, surpassing by far all the corporate education firms. This fact could also stresses the communitarian character of the Brazilian catholic institutions, eventhough these polls do not take into account the participatory development projects lead by catholic universities.

Among the Brazilian communitarian universities, the Dom Bosco Catholic University (UCDB) plays a prominent role, for its research-action projects developed within traditional and underprivileged communities, such as Amerindian or Quilombola groups (the latter being originated from century-old organized settlements laid down by runway Black slaves, in many cases absorbing bunches of deprived Amerindians, Whites and a wide range of mixed blood people). Henceforth, UCDB's mandate is strongly entrusted to serve the surrounding population on critical issues, such as social, cultural and political development. 
UCDB spreads itself throughout three campi in Mato Grosso do Sul, the Brazilian state (which total area reaches nearly 358000 $\mathrm{sq} \mathrm{km} / 138000 \mathrm{sq} \mathrm{mi}$ ) that shares wide international borders $(1200 \mathrm{~km})$ with Paraguay and Bolivia, and national borders with the states of Paraná, São Paulo, Minas Gerais, Goiás, and Mato Grosso. This state, which economy is based on cattle production and corporate agrobusiness (with special and up-to-date accent on bio-fuel technologies) brings forth a Human Development Index (HDI) of 0,848 (in 2005), the fifth position (out of 27) in Brazil. However, the HDI-M unveals huge assimetries in regional and local development, mainly with regard to the traditional communities. Since this unequal distribution of wealth is related to the deterritorialization of historical human settlements, the intra-regional social gap could be seen as the reverse result of public policies with respect to Western Brazil occupation and colonization, mainly in the course of 20th Century.

Regarding the sound and fast depopulation of Amerindian groups in that vast territory, Antonio Brand (2007) underlines the fact that in "Mato Grosso do Sul State, region crisscrossed by the megadiverse biomas of Pantanal and Cerrado, the Amerindian population is estimated at around 60000 people, nearly $10 \%$ of the whole Native population in Brazil", which raises to some 700000 people, according to the 2000 national census. Bearing the second largest aboriginal population in Brazil, Mato Grosso do Sul is quite megadiverse even on the matter of culture: those 60000 Amerindians are broadly distributed among seven autonomous Nations, with their own specific languages and cultures: Kadiwéu, Ofaiet, Terena, Guarani-Kaiowá, Kamba and Atikum.

To sketch out an illustrative parallel between North and South America, the Province of Quebec sums up a population of around 80,000 Native dwellers in 2005 (out of a 800,000 Canadian total), must of whom actually face challenging social stakes even nowadays, precisely alike their Southern ethnic counterparts : deterritorialization, socio-cultural destructuration, various chemical addictions, prostitution, juvenile and adult suicide, low education rates, disproportionate HDI, starvation. Quebec and Mato Grosso do Sul, amidst other geographic regions throughout the Americas, have a large and justified interest in sharing their respective experiences and knowledge related to those social issues.

The UCDB's academic researchers are strongly commited to the Pantanal and Cerrado region development. Articulated around the Masters Program in Education and in Local Development (both of which are periodically and systematically evaluated by the Federal Ministry of Education), as well as scientific journals and research-action projects, the academic and social activities are accomplished through a widely multidisciplinar team. Agronomists, anthropologists, communications specialists, economists, educationists, forester engineers, geographers, historians, jurists, linguists, literature specialists, managers, psychologists, sociologists are those who develop their research-action works conjointly with the traditional communities, in a fair and fertile intercooperation.

As a matter of course, indigenous students have started taking into their own hands important shares in research programs, from both Scientific Initiation Program (a national project designed to forge young researchers through scholarships and grants) and Undergraduate Final Work to the UCDB's Masters Programs. As a consequence, in the course of the last five years, four Native individuals were granted a Master's degree by UCDB, while one of them was ulterly admited into a Doctorate program, besides taking the direction of the Indigenous National Fundation regional office. Those students are firmly encouraged to work within their communities, in order to disseminate their experience and multiply the number of future students, researchers and development agents.

Despite the short period of time - ten years - spilled oud since the creation of the University and its Masters Programs, the results are much more than just promising. In 2007, the staff's strong commitement has lead to the creation of the undergraduate courses "Agroecology in Indigenous Territories », designed exclusivelly for Native 
individuals (50 students are admited each academic year). Furthermore, the "Traditional Indigenous Education" courses meet the needs and requirements of Native teachers to develop pedagogical instruments based on Amerindian culture. In every other faculty branches at UCDB, Native students are granted scholarships (60 in 2007), in addition to special support (reinforcement classes, personal advising, class materials, documentation center, computer lab), in order to ensure their access to new technologies as well as the continuation and conclusion of their undergraduate studies. To keep this policy working properly, UCDB has found partners in public, private and in the third sector, through organisms such Ford Foundation, UNICEF, various NGO's, federal ministries and state secretaries.

The role played by those researchers on traditional societies is to contribute to the production of knowledge related to the conditions under which some Amerindian communities struggle to subsist in South America. On the other hand, those studies are conceived and accomplished also to recover traditional knowledge and practices, extremely important factors leading to participatory sustainable development, whether regionally (Pantanal and Cerrado), nationally or globally. That academic work results in the revalorization of cultures longtime depreciated through the colonization historical proccess, ant it helps to redress and preserve the cultural megadiversity in Brazil. Moreover, it enhances the Native communities self-knowledge, selfesteem and feeling of belongness.

In that perspective, research-action projects are developed on a wide range of subjects, such as community gardens, traditional plants nursery, pisciculture, Amerindian languages and literatures, pedagogical means and materials, traditional handcraft, Indigenous teachers formation, sanitarian education, food security, women's empowerment, all of them nourished by and nourrishing back a documentation center (on History, Law, Culture, Agriculture, Arts, Linguistics, Literature). In this two-way knowledge lane, those activities give birth to projects driven to integrate Amerindian cultures in the UCDB's everyday life. Furthermore, the researcher team plans to publish bilingual editions of local Native literature, destinated to sensibilize young non-indigenous students, in addition to offering pedagogical means to Native language learning within the concerned communities. From this farsighted actions thread, according to Dr. Antonio Brand (chief coordinator of all UCDB's projects related to Indigenous communities), it's possible to take apart some staunch examples :

- Extension activities Indigenous Agents: This project support and train 40 Native agriculture technicians to assist their home communities on family-gardens maintenance and soil recovering, as well as on Native families assistance through women empowerment.

- Experimental Research Units: Laid down in Indigenous territories schools, these units are based on both teaching and research on traditional agricultural plant species, in order to instigate young Natives to develop alternatives for food production and processing. In addition, parallel activities are conceived and developed aiming to recover traditional handcraft (pottery, basketry, textiles, adornments) and awake craft entrepreneurship and forgotten abilities.

- Undergraduate courses on Agroecology: From 2007, the university offers a participative undergraduate course for Native individuals based on Indigenous traditional knowledge. Through documentation and research on traditional agriculture, the university combines academic activities with social practices in Indigenous territories. These activities are designed to improve Native self-confidence on traditional knowledge, and sensibilize other ethnic groups on Amerindian know-how.

- Point of culture: This activity center is recognized and funded as an official "Point of Culture" by the Brazilian Ministry of Culture, among important performing arts and culture centers spread across many countries, all of them created to preserve and promote the cultures of Brazil. UCDB's "Point of 
Culture" prepares Native teachers for basic and secondary school, through formalization and valorization of local Native culture and traditional knowledge.

- Scientific journals: Interações (Local Development, ISSN 1518-7012), Série Estudos (Education, ISSN 1414-5138) and Tellus (Indigenous social studies, ISSN 1519-9452) offer an academic space to discussions on subjects related to traditional communities, culture, and education.

The projects and actions related above have been granted an extraordinary acknowledgement at national and international levels, by means of prizes and funding support from organisms such as UNICEF, HWO, Ford Foundation, Oikos International, Fuji International, Brazilian Federal Ministries (Health, Culture, Education, National Integration), Brazilian National Funding Agencies (CNPq, CAPES), State and municipalities organisms, as well as from private sector. At the present moment, UCDB's development programs aim to expand its foreigner universities interchange network. For this reason, UCDB develops, conjointly with the UQAM's Brazilian Studies and Research Center, a large number of activities that include video conferences, mutual technical visits for researchers, co-publications, presential seminars.

\section{The joint venture Quebec-Brazil on the role of universities in local development}

The research project we are presenting here has been initiated by the Center for Enquiries and Research on Brazil (CERB), the only one research center on Brazil in the whole Canada. Created in 2001, it brings together a multidisciplinary team of about thirty Brazilianists, mainly from UQAM but also from other Quebec's universities.

The CERB has been given the following mandate :

- To bring together professors, researchers and others interested in cultural, artistic, social, scientific, economical and technological developments in Brazil and, with this perspective, to strengthen Brazilian relationships with Canada and Quebec;
- To stimulate enquiry and research programs as well as the diffusion of information on Brazil ${ }^{14}$;

- To be a reference centre on Brazil for Quebecois and Canadian academic communities and their primary civil society partners (governments, private sector...).

The theoretical framework adopted by CERB's researchers is inspired by Ignacy Sach's ecodevelopment approach, which refers not only to ecological and economic dimensions but also to a social one. In this perspective, every local or regional development plan should try to comply with the following requirements :

- A horizontal approach and a decentralized management;

- A collective, comunitarian action;

- An active social participation;

- A coordination of various actors in the social, economic, cultural and educational spheres;

- A sense of public service dedicated to the bettering of the whole collectivity.

Our ongoing research project on the role of universities in local development has been prepared through a series of videoconferences, involving Brazilian as well as Canadian colleagues, all of them sharing the same values and goals with regard to the participatory development. It is anchored in an institutional structure likely to ensure its stability and continuity. The RUQFRIB network (Réseau universitaire québécois pour la formation, la recherche et l'intervention au Brésil), created in December 2005, which gathers more than twenty researchers of five constituent of the University of Quebec network, has located there its head office. Moreover, in March 2005, the UQAM signed a multilateral agreement with eight well established Brazilian universities. Later on, in 2006, the Universidade do Mato Grosso joined the network and UCDB has become in 2007 the $10^{\text {th }}$ brazilian institution applying to become a full member of this academic consortium, which the Brazilian collaborators to this project belong to ${ }^{15}$. This agreement, governed by an orientation council which meets at least once a year, creates in fact a network (called BRACERB) which will 
provide excellent conditions for an ongoing cooperation. Moreover, the relations established by several members of the team with Spanish-speaking researchers make it possible to consider an extension of collaboration to other countries in Latin America. Lastly, the CERB is a partner of the Canadian Visiting Research Chair in Brazilian Studies, subsidized by the International Development Research Council (IDRC), gathering five Canadian universities (Calgary, Saint-Mary' S, UQAM, Western Ontario, York).

Our research, subsidized within the framework of the program "International Initiatives" of the Social Sciences and Humanities Research Council (SSHRC), proposes to identify these studies and practices, to share the resulting expertise, to push the reflexion a little further and to work out other innovating models regarding transfering and sharing knowledge. The objective is to allow the Brazilian and Québécois researchers and practitioners to take advantage of their reciprocal expertise but also to enable them to develop joint projects of intervention in other countries of the lusophone (Mozambique, Angola, Capo Verde, Guinée Bissau) and the francophone worlds (West Africa and Haiti).

The four canadian and the five brazilian universities' reseachers participating to our research program will proceed to a systematic study of the principal means adopted by the universities to ensure an active presence in their local communities and to support the transfers/ exchanges of knowledge, in three specific areas of great current relevance (local development, environmental sciences and studies in tourism). Among all these means, we will give priority to the programs conceived specifically to meet needs expressed by specific social groups, to training and research activities runned by the institutional Services to the communities or Extension Services. They are usually conceived and led in collaboration with community organizations, non-profitmaking associations and trade unions, under various forms of private/public or public/ public partnership. Lastly, we will pay special attention to training courses involving students' participation in local organizations or communities, offered by various programs, making the assumption that they constitute major paths for the transmission of knowledge and the exchange of information.

For each one of these means, we will proceed to an inventory of the relevant experiments conducted during the last ten years within the Québécois and Brazilian universities participating to the project. Case studies will focus on projects trying to achieve ecodevelopment in a participative way. We will make a systematic description, focusing on the conditions of realization, and we will look for the factors which favor or impede the exchanges of knowledge. On a theoretical level, we will review, in a critical perspective, the principal approaches refering to the transfer of knowledge (terminology and approach disputed by several authors), to the participative or collaborative training, to anchored research and to the use of the convincing data and the investigation of needs.

Interdisciplinarity seems to us an essential component of the innovative practices in the production and transfer of knowledge. The relations that already link one to the other the fields of local development, environmental sciences and tourist studies (durable tourism) explain why we selected these areas. Local development can certainly build on various economic sectors. We chose to stress the environmental and tourist areas because they registered important growth in the Brazilian and Québécois universities over the last years, in response undoubtedly to an increasing social request.

Brazil must face considerable challenges regarding urban development and environmental protection. Amazonia undergoes the attacks of deforestation and over-populated cities must face all the problems of great modern agglomerations (poverty, homelessness, violence, lack of housing, pollution, etc). Several Brazilian universities worked out programs to contribute to the resolution of these problems, focusing on local development, on the environment and on tourism. The Canadian universities can also contribute 
their share. For its part, Canada, which must also face many environmental challenges as well as urban planning problems, can certainly draw lessons from the Brazilian history as well as from Brazilian universities innovative experiences.

The whole project pursues the following goals:

- To confront various approaches on the role of universities in the development of local communities

- To identify the conditions favourable to exchanges and transfers of knowledge

- To discuss the finalities of the convincing data

- To specify the conditions to preserve scientific freedom and the autonomy of the universities

- To identify modes of evaluation of request and needs

- To inventory the methods evaluation of the quality of services to the population

- To propose indicators of impact of the universities in local development.

Our project implies the participation of seventeen Brazilian and Canadian researchers working in various disciplines. M.A. and Ph.D students in social sciences, particularly those which are under supervision by one of the participating professors in the project, are invited to take part to the videoconferences, the seminars and the conferences. The results of our comparative analysis will also enrich the content of courses and seminars given by the professors involved in the project, reaching a few hundreds of students, in Brazil as in Quebec. We also hope to support the production of theses on the topic of the transfers/exchanges of knowledge and on the role of universities in local development.

\section{Conclusion}

The University of Quebec network has been, since its creation at the end of the Sixties, a stimulative institution for developing innovative programs and experimenting new forms of relationships to the local communities.

Brazil has, for its part, a strong tradition of popular education. Since the years 1980, researchers work with organizations of local development to reinforce integration between theory and practice. For example, many universities have created "extension services" to help their professors and reseachers to get involved in activities of teaching and research adapted to the community's needs. The courses and research projects are jointly elaborated with leaders and professionals of local development to solve their problems and gaps. The idea is that the community can use and adapt specific knowledge produced in the universities likely to have an immediate utility (WANDERELY, 2002; 133). A sound example of Brazilian universities' intervention in the community is given by the Unitrabalho experiment initiated when 32 universities signed protocols with trade-union federations empowering multidisciplinary local centers to develop consultation, training and research activities.

Brazil has also become an important partner in ecological research. It has been one of the first countries, for example, to adopt a national policy for the management of water. A recent inventory enabled us to identify, in the nine Brazilian universities taking part in the BRACERB network, an impressive number of graduate studies programs related to our research project's main topics: three (3) programs on local/regional development; nine (9) programs in environmental studies; one (1) specializing in tourism, one (1) program in remote teaching and four (4) programs in city planning.

This research process will make it possible to feed the development of a graduate program in local development, as well as the design of intervention and research projects aiming at the improvement of the living conditions of urban communities in the Brazilian Nordeste. Moreover, it will produce other outputs like running a website throughout the duration of the project; and publishing a book, in both French and Portuguese, standing for our two conferences Proceedings. We also plan to extend the benefits of the expertise developed in Brazil and Canada to countries with low scores on the scale of human development indicator (UNDP, 2006) and 
where we have contacts, in the francophone area (Haiti and West Africa) as well as in the lusophone one (Angola, Mozambique, Guinea Bissau), by contributing to the settingup of programs implying universities in local development.

\section{Notes}

${ }^{1}$ Innis, H. A. (1951), The Bias of Communication, Toronto, The University of Toronto Press, 1977, p. 195.

${ }^{2}$ Westfall, William (1981), « The Ambivalent Verdict : Harold Innis and Canadian History ", in Culture, Communication and Dependency, Melody, W., Salter, L., Heyer P. (ed.), Norwood, Ablex Publishing, p. 44

${ }^{3}$ We express our gratitude to SSHRC for the allocation of the grant number 861-2006-2088.

${ }^{4}$ The Université du Québec en Outaouais, the Université du Québec à Montréal, the Université du Québec à Trois-Rivières and the Télé-Université.

${ }^{5}$ The Universidade Federal de Santa Catarina, the Universidade Federal de Minas Gerais, the SENAC of São Paulo and the Universidade Católica Dom Bosco de Campo Grande.

${ }^{6}$ http://www.sac.uqam.ca/

${ }^{7}$ http:/ / www.feminismeetdemocratie.ca/

${ }^{8}$ Le Centre de documentation sur l'éducation des adultes et la condition féminine (CDÉACF), Nouveau Départ National, l'Association féminine d'éducation et d'action sociale (Afeas), le Regroupement provincial des maisons d'hébergement et de transition pour femmes victimes de violence conjugale et Relaisfemmes.

${ }^{9}$ http:/ / www.fadafem.ca/

${ }^{10}$ http:/ / www.chezstella.org/

${ }^{11}$ La Table d'aménargement du Quartier HochelagaMaisonneuve.

${ }^{12}$ Confédération des Syndicats Nationaux, Centrale des Syndicats du Québec, Fédération des Travailleurs du Québec.

${ }^{13}$ In June 2007, one canadian dollar is worth 0.95 american dollar and 0.70 euro.

${ }^{14}$ Among other activities, the CERB organized, in collaboration with the Institute of Environmental Sciences, from March 30 to April 1, 2005, a forum entitled BRAZIL SCIENCES AND SOCIETY, which was held in the Montreal's Biodôme of Montreal. It also organized, with the Brazilian association INTERCOM, two conferences Brazil Canada in communications, the first one in Salvador de Bahia in September 2002 and the second one in Montreal in October 2005. The different constituents of the University of Quebec network have developed over the years a widely acknowledged know how on services to the communities and in the creation of programs of local or regional development. One finds there a great concentration of competent resources in environmental sciences, in education relating to the environment, in tourist studies, in public policies, in communications and remote training (TÉLUQ), working at the Institute of environmental sciences, at the Heritage Institute, at the International Research Training Center in tourism (CIFORT), at the
Canadian Research Chair in Education relating to the environment and at the Chair on Tourism of the École des Sciences de la gestion (Management Sciences School).

${ }^{15}$ The UCDB and the CERB have been cooperating together since 2004, starting with Professor Marcelo Marinho's two year period working as a Lecturer in Brazilian culture at UQAM.

\section{References}

ASSEMBLÉIA NACIONAL CONSTITUINTE. Atas das Comissões, n. 96. Brasília, Congresso Nacional, 1987.

BERKES, F.; FOLKE, C. Linking social and ecological systems. Management practices and social mechanisms for building resilience. Cambridge : Cambridge University Press, 2000. 459 p.

BETTEZ, Monique. La recherche universitaire, vecteur $d u$ développement endogène régional: le cas de l'Université du Québec à Chicoutimi au Saguenay-Lac-Saint-Jean. Thesis in Master of Sciences. Chicoutimi, UQAC, 1999.

BRAND, Antonio. Povos indígenas na região do Pantanal e do Cerrado: desenvolvimento participativo, universidades e pesquisa-ação, 2007. Available in: <http:// www.unites.uqam.ca/bresil/Francais/Nouvelles/ brandUQAM2007.pdf>. Accessed: 14 jan. 2007.

BRETON, Gilles. Globalisation et universités. Paris : UNESCO; Québec : Presses de l'Université Laval, 2003.

BRETON G.; LAMBERT M. (Eds.). Globalisation et université. Nouvel espace, nouveaux acteurs. Paris, Economica, 2003. 264 p.

BRUNET, N. Elaborating an integrated and participatory model for ecodevelopment in coastal zones. In: VIEIRA, P.F. (Org.). Conservação da diversidade biológica e cultural em zonas costeiras. Enfoques e experiências na América Latina e no Caribe. Florianópolis: APED, 2003. p. 373-384.

COIMBRA, A. O outro lado do meio ambiente. Campinas, Millennium, 2002. 527 p.

DELORS, Jacques. L'éducation pour le XXI siècle, questions et perspectives. Contributions à la Commission internationale sur l'éducation pour XXIe siècle. Paris: UNESCO, 1998.

DESGAGNÉ, Serge. La participation de l'usager, praticien ou citoyen, à la production d'un savoir crédible: une aventure incontournable. In : SAUVE, L.; ORELLANA, I.; VAN STEENBERGHE, E. (Dir.). Éducation et environnement. Un croisement de savoirs. Collection Les Cahiers scientifiques de L'ACFAS. Montréal: ACFAS (Association francophone pour le savoir), 140, 2005. p. 175-186.

DOWBOR, L.; TAGNIN, R.A. (Org.). Administrando a água como se fosse importante. Gestão ambiental e sustentabilidade. São Paulo, SENAC, 2005. 290 p.

FONTAN, J.M.; KLEIN, J.L.; TREMBLAY, D.G. Innovation sociale et reconversion économique. Le cas de Montréal. Paris: L'Harmattan, 2005.

Collective Action in Local Development: the Case of Angus Technopole in Montreal, Canadian Journal of Urban Research, v. 13, n. 2, p. 317-336, 2005. 
FREIRE, Paulo. Pédagogie de l'autonomie: savoirs nécessaires à la pratique éducative. Translated by JeanClaude Régnier. Ramonville-Saint-Agne: Erès, 2006. $191 \mathrm{p}$.

Teachers as Cultural Workers: Letters to Those Who Dare Teach. Translated by Donaldo Macedo, Dale Koike and Alexandre Oliveira. Boulder: Westview Press, 1998.

. Pédagogie des opprimés. Suivi de Conscientisation et révolution. Paris: Maspéro, 1977. 202 p.

FUNDAÇÃO PREFEITO FARIA LIMA. O Município no século XXI: cenários e perspectivas. São Paulo: FPFL, 1999. $400 \mathrm{p}$.

GADOTTI, Moacir. Universidade estatal, Universidade comunitária: dois perfis em construção da universidade brasileira. Available in: <www.paulofreire.org/ Moacir_Gadotti/Artigos/Portugues / Educacao_Brasileira/Universidade_estatal_.pdf $>$. Accessed: 14 jan. 2007.

GOLDSTEIN, Reine. Université et société: pour en finir avec un long malaise, Paris: L'Harmattan, 2003.

HARDOY, J.E.; MITLIN, D.; SATTERTHWAITE, D. Environmental problems in Third World cities. London, Earthscan, 1992. 302 p.

HUDON, Raymond. Villes, régions et universités: les acteurs et leurs pratiques, compte rendu de la première édition des Rencontres Champlain-Montaigne, Québec, 3-5 octobre 2001. Textes colligés par Raymond Hudon et Jean-Pierre Augustin, Sainte-Foy: Presses de l'Université Laval ; Talence: Maison des sciences de l'homme d'Aquitaine, 2002.

INNIS, H. A. (1951). The Bias of Communication. The University of Toronto Press, 1977.

JOYAL, André; MARTINELLI, Dante. O desenvolvimento local e o papel das pequenas e médias empresas. São Paulo, Manole, 2004. 314 p.

KLEIN, J.L.; MANZAGOL, C.; TREMBLAY, D.G.; ROUSSEAU, S. Les interrelations université-industrie à Montréal dans la reconversion à l'économie du savoir. In : Guillaume, R. Globalisation, Systèmes productifs et dynamiques territoriales. Paris: l'Harmattan, 2005. 328 p.

KLEIN, J.L.; TREMBLAY, D.G.; FONTAN; J.M. Mundialización, acción colectiva e iniciativa local en la reconversión de Montreal. Revista Latinoamericana de Estudios Urbanos y regionales, v. XXIX, n. 86, p. 59-75, mai 2003.

LEV ZIMMERMAN, Enrique. Savoir environnemental: épistémologie, rationalité et dialogue de savoirs. Enjeux et défis pour l'éducation. In: SAUVE, L.; ORELLANA, I.; VAN STEENBERGHE, E. (Dir.). Éducation et environnement. Un croisement de savoirs. Collection Les Cahiers scientifiques de L'ACFAS. Montreal: ACFAS (Association francophone pour le savoir), 140, 2005. p. 49-66.

RAPOSO, Mário Lino; SERRASQUEIRO, Zélia Silva. O papel da universidade e o desenvolvimento regional. In: Cadernos de Economia. Available in: <http:// ww w .cadernoseconomia.com.pt / ce71 / mario_lino_raposo.pdf> Accessed: 30 jan. 2007.
MARTELETO, Regina Maria e Silva; OLIVEIRA, Antonio Braz de. Redes e capital social: o enfoque da informação para o desenvolvimento local. Ci. Inf. [online], v. 33, n. 3, p. 41-49. Available in: <http:// www.scielo.br/scielo.php?script=sci_arttext\&pid= S0100-1965200400030000>. Accessed: 30 jan. 2007.

MORIN, Édgar et al. Le défi du XXI siècle: Relier les connaissances. Paris: Éditions du Seuil, 1999.

MATHIEU, N.; GUERMONT, Y. (Ed.). La ville durable, du politique au scientifique. Paris: Cemagref/Cirad/ Ifremer/INRA, 2005. $285 \mathrm{p}$.

OCDE. Global knowledge flows and economic development. Paris: OCDE, 2004.

. Internationalization of Higher Education. Paris, OCDE, 1996.

Les technologies de l'information et l'avenir de l'enseignement post-secondaire. Paris: OCDE, 1996.

ORELLANA, Isabel. La communauté d'apprentissage en éducation relative à l'environnement, signification, dynamique, enjeux. Thesis in Philosophical Doctorate. Montreal: Université du Québec à Montréal, 2002.

. L'émergence de la communauté d'apprentissage ou l'acte de recréer des relations dialogiques et dialectiques de transformation du rapport au milieu de vie. In:SAUVE, L.;ORELLANA, I.; VANSTEENBERGHE, E. (Dir.). Éducation et environnement. Un croisement de savoirs. Collection Les Cahiers scientifiques de L'ACFAS. Montréal: ACFAS (Association francophone pour le savoir), 140, 2005. p. 67-84.

ORGANISATION MONDIALE DU TOURISME (OMT). Le tourisme et la réduction de la pauvreté. Madrid: OMT Press, 2002. $115 \mathrm{p}$.

OMT. Le tourisme et la réduction de la pauvreté recommandation pour l'action. Madrid: OMT Press, 2004. $47 \mathrm{p}$

. La valorisation de l'apport économique du tourisme pour les communautés locales et la réduction de la pauvreté. Madrid: OMT Press, 2002. 65 p.

. Le potentiel du tourisme comme stratégie de développement durable. Madrid: OMT Press, 2005. 162 p. 2005. $209 \mathrm{p}$

Vers un tourisme durable. Madrid: OMT Press,

Développement durable du tourisme: Guide à l'intention des autorités locales. Madrid: OMT Press, 1998. $194 \mathrm{p}$.

. Guide à l'intention des autorités locales pour le développement durable du tourisme: Volumes supplémentaires. Madrid: OMT Press, 1999.

Indicateurs du développement durable des destinations touristiques. Madrid: OMT Press, 2004. 514 p.

Le tourisme rural, une solution pour l'emploi, le développement local et l'environnement. Madrid: OMT Press, 1997. 107 pages.

PETRELLA, Ricardo. L'éducation, victime de cinq pièges. À propos de la société de la connaissance. Montréal: Fides, 2000.

RIBEIRO, M.A. Ecologizar. Pensando o meio ambiente. Belo Horizonte: Rona, 1998. 390 p. 
SANZ, Nuria et Sjur Bergan. Le patrimoine des universités européennes. In: Enseignement supérieur du Conseil de l'Europe. n. 7, 2007.

SAUVE, L.; ORELLANA, I.; VAN STEENBERGHE, E. (Dir.). Éducation et environnement. Un croisement de savoirs. Collection Les Cahiers scientifiques de L'ACFAS. Montréal: ACFAS (Association francophone pour le savoir), 140, 2005

SENGE, Peter. The fifth discipline: The art and practice of the learning organization. New York: Currency Doubleday, 1990.

TREMBLAY, Diane-Gabrielle (Org.). Formation et performance socio-économique; comparaisons internationales. Québec: PUQ, 2006.

Virtual Communities of practice: towards a new mode of Knowledge sharing and learning? In: RUZICKA, R.; BALLANTNE, J.H.; SAN ROMAN, J.A. Ruiz (Ed.). Key Contexts for Education and Democracy in Globalising Societies. Prague: Accentura M Agency Charles University, 2004. p. C117-124.

TREMBLAY, Diane-Gabrielle et $S$. Rousseau. Politique d'aménagement et multimédia à Montréal; la reconversion par une gouvernance mixte. Dans Tremblay, Diane-Gabrielle et Rémy Tremblay (sous la dir., 2006). La compétitivité urbaine dans le contexte de la nouvelle économie. Québec: Presses de l'université du Québec, 2006.

TREMBLAY, Diane-Gabrielle et P. Doray (2000, sous la dir.). Vers de nouveaux modes de formation professionnelle? Rôle des acteurs et des collaborations. Québec: Presses de l'Université du Québec, 2000. 278 p.

TREMBLAY, Diane-Gabrielle et Jean-Marc Fontan. Le développement économique local; la théorie, les pratiques, les expériences. Québec: Presses de l'Université du Québec, 1994. 579 p.

TREMBLAY, Diane-Gabrielle. Le rôle des universités dans le développement économique: faire émerger les "facteurs invisibles" essentiels au développement, dans Université du Québec. Le Québec urbain et celui des régions face à la nouvelle économie mondiale. Sainte-Foy: Bureau des études prospectives et du développement/ Vice-présidence à la planification, Université du Québec, 1993. p. 50-84.

TREMBLAY, Gaëtan. Redes de comunicación, Aprendizaje y Sociedad. In: BOLAÑO, César; MASTRINI, Guillermo; SIERRA, Francisco (ed.). Economía política, comunicación y conocimiento: una perspectiva crítica latinoamericana. Buenos Aires: Ediciones la Crujía, 2005. p. 123-148.
Les partenariats. Stratégies pour une économie du savoir. Distances et savoirs, Paris, v. 1, n. 2, p. 191208, 2003.

Campus virtuels. Du Siècle des Lumières à l'économie du savoir. Terminal, n. 83, p. 33-45, 2000.

Prototypes de campus virtuel à l'Université du Québec. In: FICHEZ, Élizabeth; DECEUNINCK, Julien (Org.). Industries éducatives, situation, approches et perspectives. Lille, 2000. p. 167-176.

. De l'enseignement à distance au campus virtuel. Enjeux de l'utilisation des TIC dans la formation universitaire. In: LECLERC, Michel (Org.). Disparition ou réorganisation du travail? Québec: Presses de l’Université du Québec, 1999. p. 78-96.

UNDP. Human Development Report 2006. Beyond scarcity: power, poverty and the global water crisis. New York, United Nations Development Programme, 2006. 422 p. Available in: <http://hdr.undp.org/hdr2006/pdfs/ report/HDR06-complete.pdf>. Accessed: 30 jan. 2007.

UNESCO. Vers les sociétés du savoir. Paris:UNESCO, 2005.

VIEIRA, P.F. Éducation pour l'écodéveloppement au Brésil: promesses et incertitudes. Éducation relative à l'environnement. Chaire de recherche $d u$ Canada en éducation relative à l'environnement, v. 4, p. 57-75, 2003. Montreal, UQAM.

VIEIRA, P.F.; RIBEIRO, M.A.; FRANCO, R.M.; CORDEIRO, R.C. (Org.). Desenvolvimento e Meio ambiente no Brasil. A Contribuição de Ignacy Sachs. Porto Alegre: Pallotti; Florianópolis: APED, 1998. 448 p.

VIGOTSKY, Lev. Mind in society: the development of higher pshychological processes. Cambridge: Harvard University Press, 1978.

SILVA, Enio Waldi da. Extensão e Desenvolvimento Regional: Discurso das Universidades Comunitárias do Rio Grande do Sul. In: ${ }^{\circ}$ CONGRESSO BRASILEIRO DE EXTENSÃO UNIVERSITÁRIA. Anais ... 2004. Available in: <http://www.ufmg.br/congrext/ Avalia/Avalia3.pdf>. Accessed: 28 jan. 2007.

WANDERLEY, Luiz Eduardo W. ONGs e universidades: desafios atuais. In: HADDAD, Sérgio (Org.). ONGse universidades: desafios para a cooperação na América Latina. São Paulo: Abong/Peirópolis, 2002. p. 119-142.

WESTFALL, William. The Ambivalent Verdict: Harold Innis and Canadian History. In: MELODY, W.; SALTER, L.; HEYER P. (Ed.). Culture, Communication and Dependency. Norwood: Ablex, 1981. 